\title{
Spatio-temporal influence of physicochemical parameters on phytoplankton assemblage in coastal brackish lagoon: Gomishan Lagoon, Caspian Sea, Iran
}

\author{
MOHAMMAD JABBARI ${ }^{1, \boldsymbol{v}}$, MORTEZA SALAHI ${ }^{2}$, RASOUL GHORBANI ${ }^{3}$ \\ ${ }^{1}$ Faculty of Fisheries and Environment, Gorgan University of Agricultural Science and Natural Resources. Gorgan, Golestan, Iran. \\ Tel.: +98-935-521-9949, `email: m.jabari91@yahoo.com \\ ${ }^{2}$ Department of Fisheries, Faculty of Marine Sciences and technology, Hormozgan University, Bandar Abbas, Iran \\ ${ }^{3}$ Department of Fisheries, Faculty of Fisheries and Environment, Gorgan University of Agricultural Science and Natural Resources. Gorgan, Golestan, \\ Iran
}

Manuscript received: 19 July 2017. Revision accepted: 17 October 2018.

\begin{abstract}
Jabbari M, Salahi M, Ghorbani R. 2018. Spatio-temporal influence of physicochemical parameters on phytoplankton assemblage in coastal brackish lagoon: Gomishan Lagoon, Caspian Sea, Iran. Biodiversitas 19: 2020-2027. The objective of this study was to determine the spatiotemporal distribution pattern of phytoplankton assemblage due to physico-chemical heterogeneity in coastal brackish lagoon of Gomishan. An inter-annual cycle of sampling period (April 2014-March 2015) and spatially stratified random sampling were established to examine 24 spatiotemporal scenarios. Water samples were preserved in 1 and 0.5 liter dark Polythene bottles from each station for assessing plankton community and chlorophyll $a$, respectively. The applied multivariate approach including hierarchical cluster analysis for (dis)similarity test of environmental factors, principle component analysis (PCA) and canonical correspondence analysis (CCA) was used to illustrate the pattern of phytoplankton variability in relation to environmental characteristics. The results showed that mean salinity, temperature, $\mathrm{pH}$, total nitrogen, phosphorus, silica, turbidity, and electrical

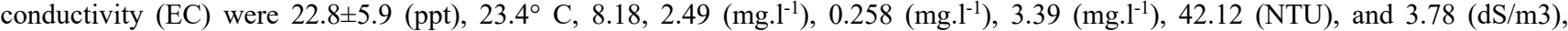
respectively. Scenarios S5AT, S5W, S6W, S6AT were distinguished from other scenarios with more than 90\% similarity, subsequently S1SU and S5SU with about $80 \%$ similarity. Inter-annual mean density of total phytoplankton (cell. $1^{-1}$ ) was $2.45 \times 10^{6}$, whereas in northern sector it was constant with only a peak in June, but in southern sector it was more tolerant, so in April it tended to increase with a peak $\left(7.2 \times 10^{6}\right)$ in July which was the maximum density over the year. The phytoplankton assemblage of the lagoon comprised 47 species from 5 different classes including Bacillariophyta, Pyrrophyta, Chlorophyta, Cyanophyta, and Euglenophyta.
\end{abstract}

Keywords: Caspian Sea, environmental factors, Gomishan Lagoon, phytoplankton assemblages

\section{INTRODUCTION}

"Transitional waters" for this research and implemental guidance, have been described by EU Water Framework Directive (2000/60/EC) as "bodies of surface water in the vicinity of river mouths which are partly saline in character as a result of their proximity to coastal waters but which are substantially influenced by freshwater flows". Furthermore, coastal waters are defined as "surface water on the landward side of a line, every point of which is at a distance of one nautical mile on the seaward side from the nearest point of the baseline from which the breadth of territorial waters is measured, extending where appropriate up to the outer limit of transitional waters" (European Communities 2000). According to Ramsar classification for wetland systems, Gomishan wetland is classified as a coastal brackish lagoon that is permanent shallow water separated from the Caspian Sea by a barrier which makes it more restricted inlet water body with at least one relatively narrow connection to the sea, and in this case, Gomishan Lagoon is oriented parallel to the coastline of Caspian Sea (Hails 1997).
Ecologically, coastal lagoons as a "transitional water" play a critical role in all nearby ecosystems and their ecological services in these habitats are very important such as nursery ground for aquatic species (fishes and invertebrates) (Spatharis et al. 2007), and other associated organisms. Gomishan coastal lagoon is considered to be an Ecotone, which is a transitional zone from aquatic to terrestrial ecosystems (Odum and Odum 1959). Due to spatial and temporal heterogeneity of Physico-chemical characteristics such as turbidity (nutrients inflow of river), temperature and salinity, lagoon ecosystems are likely to have high local biodiversity and biomass productivity of fishes, macro-benthic, micro-invertebrates, planktonic fauna and flora, and especially phytoplankton (Barbone and Basset 2010).

Phytoplankton are the foundation of aquatic food chain in both marine and freshwater ecosystems . Phytoplankton species produce about $95 \%$ of marine production in a coastal area that is indirect or direct source of energy for a wide range of marine consumers from microscopic zooplankton to large Whales (Nielsen 1975). Quantitative studies on phytoplankton population dynamic and distribution pattern are important for the modification of 
eutrophication and trophic level of aquatic systems, determination of harmful alga bloom (Viličić 1989) and understanding of its impact on water quality (Bartram and Ballance 1996).

In the following references, some physical, chemical and biological factors are found to cause the spatial and temporal changes of phytoplankton abundance and distribution pattern in coastal lagoons. Inorganic nutrition limits including Nitrate, Phosphate, and Silica leads to phytoplankton's biomass environmental capacity and physiological limitation (Smayda 1980); photosynthetic production needs light (Kirk 1994); physical factors such as wind, tidal flushing, and hydrologic cycles affect phytoplankton bloom (both harmful and useful alga bloom) in costal habitats (Cloern 1996); and most recently, phytoplankton dynamic controllers are described as nutrient level, light availability, temperature, $\mathrm{pH}$, dissolved oxygen, relative buoyancy, wind, hydrodynamic factors and grazing (Paerl 1988; Philips et al. 2002).

The aims of this study, based on spatial and temporal data analyses, were to characterize physico-chemical factors influencing phytoplankton guild, and to determine phytoplankton distribution pattern in Gomishan Lagoon, Caspian Sea. The considered factors were dissolved Oxygen (DO), salinity, electrical conductivity (EC), water temperature, $\mathrm{pH}$, turbidity, Phosphate $\left(\mathrm{PO}_{4}, \mathrm{P}, \mathrm{P}_{2} \mathrm{O}_{5}\right)$, Nitrate $\left(\mathrm{NO}_{3}, \mathrm{~N}-\mathrm{NO}_{3}\right)$, and Silica $\left(\mathrm{Si}, \mathrm{SiO}_{2}\right)$ measured in spatially and temporally distributed sampling sites in study area. The result of this study will be used for ecological sustainability monitoring and developing a blooming pattern in the Gomishan Lagoon.

\section{MATERIALS AND METHODS}

\section{Study site}

Gomishan Lagoon is a coastal permanent brackish lagoon at the southeast coastal area of the Caspian Sea which is one of the largest inland aquatic systems. It's an international transitional water along coastline of Caspian Sea from the Golestan State's local government in Iran to Gomishan area in the Turkmenistan. Geographically, it is located between $37^{\circ} 9^{\prime}$ to $37^{\circ} 20^{\prime} \mathrm{E}$ and $53^{\circ} 54^{\prime}$ to $53^{\circ} 58^{\prime} \mathrm{N}$ (Figure 1). The width and depth of the Gomishan Lagoon mostly depend on water input of Volga river (with the average annual depth of 1.36 meters) into the Caspian Sea and fluctuation of sea level. At the time of this study (20142015), it had around 72 kilometers mean length and 3.5 kilometers mean width along the coastline of Caspian Sea.

\section{Data collection}

Well distributed sampling stations in spatial and temporal scale were established to ensure that collected samples were representatives of Gomishan Lagoon system. Samples were taken every month over a year (early April 2014 to late March 2015) and stratified random sampling was carried out for dividing the lagoon into 6 strata named $\mathrm{S} 1$ to S6, respectively ordered from northern to the southern parts of the lagoon. Within the Strata, 3 sampling stations were sorted by water depth, so vertically there were 3 different depths but randomly distributed in a horizontal profile. Water samples were preserved in 1 and 0.5 liter dark Polythene bottles from each station for assessing plankton community and chlorophyll $a$, respectively. Samples were returned to the laboratory in a cooling box for extra examination.

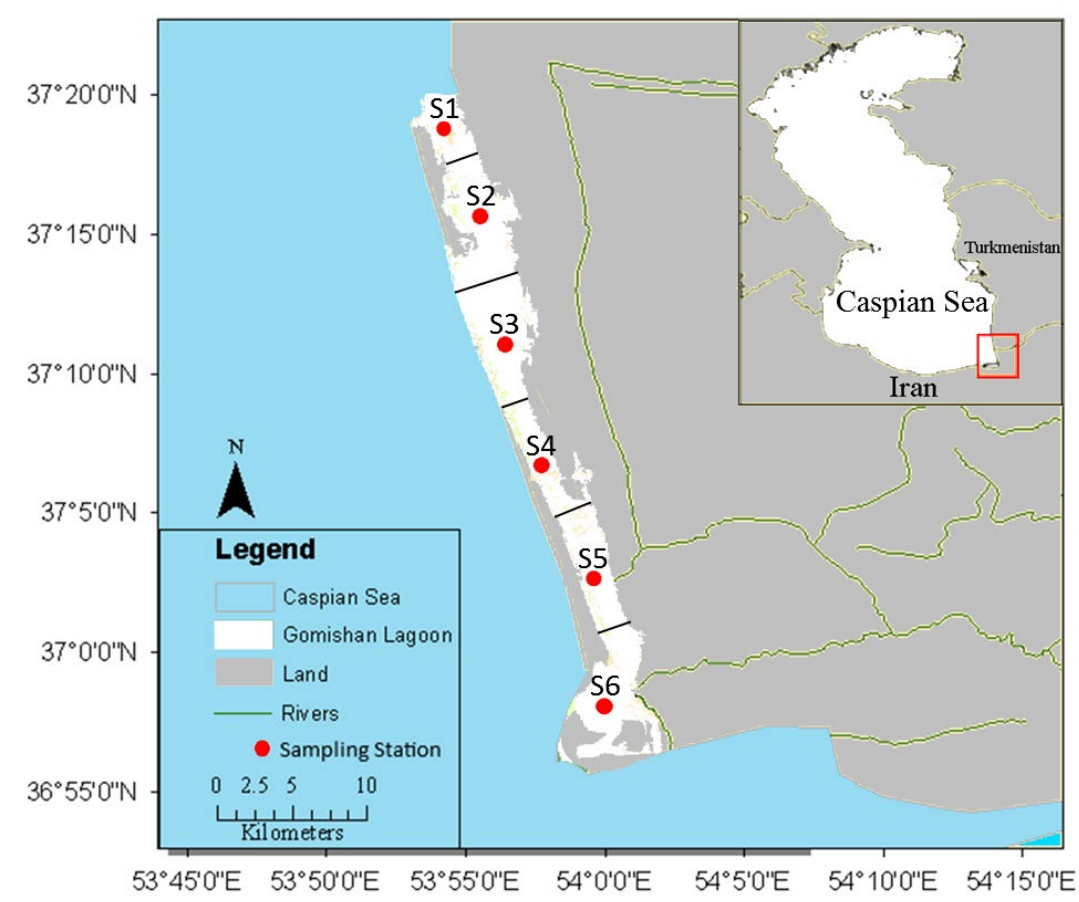

Figure 1. Study area. Sampling sites (S1-S6) and stratified sectors in Gomishan Lagoon, Iran 


\section{Laboratory measurements and identification}

The physic-chemical parameters measured were DO (mg/L), Salinity (ppt), EC (s/m), WT (C), pH, Turbidity (NTU), $\mathrm{PO} 44, \mathrm{P}, \mathrm{P}_{2} \mathrm{O}_{5}, \mathrm{NO}_{3}, \mathrm{~N}_{-} \mathrm{NO}_{3}, \mathrm{Si}$. The $\mathrm{SiO}_{2}$ was measured with YSI/portable probes model DR 2800 Hach and examined using the standard method for water and waste water (APHA 2012). Phytoplankton species identification keys used the following references: Marshall 1986; Moncheva and Parr 2010. The analyzed phytoplankton have been checked by laboratories and experts that are experienced in the field of phytoplankton analysis such as laboratory of Gorgan University of Agricultural Sciences and Natural Resources, and Hormozgan University. Average biovolume and occurrence of each recognized phytoplankton were calculated and classified into 5 functional groups (Diatoms, Dinoflagellates, Green algae, Cyanobacteria, Euglenoids) for further statistical analysis.

\section{Data analyses}

Multivariate approach was used for statistical analysis to illustrate biotic and abiotic change pattern and correlation between environmental parameters and phytoplankton distribution. Spatio-temporal analysis of physico-chemical parameters was done by creating 24 scenarios that were combinations of 4 season and 6 sites (Table 1). (Dis)similarity of scenarios analysis were created with hierarchical cluster analysis. Principle Component Analysis (PCA) and canonical correspondence analysis (CCA) were applied to reveal the pattern of phytoplankton variability in relation to environmental characteristics using $\mathrm{R}$ package "Vegan". Relative abundance comparison was analyzed with one-way ANOVA at $<0.05$ confidence level using $\mathrm{R}$ programming language.

\section{RESULTS AND DISCUSSION}

Overall, measured physical and chemical water quality parameters fluctuated over time and space (Table 2).
Physicochemical characteristics are described as follows in order to develop a change pattern: $\square$

\section{Salinity, temperature, and $\mathbf{p H} \square$}

Salinity of Gomishan Lagoon with mean $( \pm \mathrm{SE})$ $22.8 \pm 5.9$ (ppt) has changed from 13.1 unit in Autumn up to 35.8 (ppt) in summer. Spatially, minimum and maximum of salinity were observed in Sites S6 and S1 which were significantly different from others with 8.4 and 32.5 (ppt), respectively. Water temperature (WT) with a range of 12.8 to 31.1 centigrade and mean degree of 23.4 differed not significantly among the sites. Mean $\mathrm{pH}$ was 8.18 , ranging from 7.94 in winter months to 8.94 in site S6 (Table 2).

\section{Total nitrogen, phosphorus, and silica $\square$}

Mean total Nitrogen concentration was $2.49\left(\mathrm{mg} . \mathrm{l}^{-1}\right)$ with minimum and maximum of 1.4 to 4.46 that occurred during spring and station S1, respectively. Mean observed phosphorus concentration was $0.258\left(\mathrm{mg} . \mathrm{l}^{-1}\right)$ with a low level in spring and summer but significantly higher level in autumn, and tended to decrease in the winter. Concentration of total phosphorus was also significantly higher at the site S5 (Table 2). Total Silica (TS) with mean concentration of $3.39\left(\mathrm{mg} . \mathrm{l}^{-1}\right)$ was at the highest level in winter and decreased to 2.5 (mg..$\left.^{-1}\right)$ in spring season. The minimum and maximum of TS were discovered in site $\mathrm{S} 2$ and $\mathrm{S} 5$ relatively.

Table 1. Spatio-temporal scenarios for physic-chemical similarity analysis in Gomishan Lagoon, Iran

\begin{tabular}{|c|c|c|c|c|}
\hline \multirow[b]{2}{*}{ Site } & \multicolumn{4}{|c|}{ Season } \\
\hline & $\begin{array}{c}\text { Winter } \\
\text { (W) }\end{array}$ & $\begin{array}{l}\text { Spring } \\
\text { (SP) }\end{array}$ & $\begin{array}{c}\text { Summer } \\
\text { (SU) }\end{array}$ & $\begin{array}{c}\text { Autumn } \\
\text { (AT) }\end{array}$ \\
\hline S1 & S1W & S1SP & S1SU & S1AT \\
\hline S2 & S2W & S2SP & S2SU & S2AT \\
\hline S3 & S3W & S3SP & S3SU & S3AT \\
\hline S4 & S4W & S4SP & S4SU & S4AT \\
\hline S5 & S5W & S5SP & S5SU & S5AT \\
\hline S6 & S6W & S6SP & S6SU & S6AT \\
\hline
\end{tabular}

Table 2. Physical and chemical characteristics of water quality of Gomishan Lagoon, Iran (2014-2015)

\begin{tabular}{|c|c|c|c|c|c|c|c|c|c|c|}
\hline \multirow{2}{*}{ Parameters } & \multicolumn{4}{|c|}{ Season } & \multicolumn{6}{|c|}{ Site } \\
\hline & Winter & Spring & Summer & Autumn & S1 & $\mathbf{S 2}$ & S3 & S4 & S5 & S6 \\
\hline$\overline{\mathrm{DO}(\mathrm{mg} / \mathrm{L})}$ & $10.7 \pm 0.6^{*}$ & $5.65 \pm 0.8^{*}$ & $7.64 \pm 2.2$ & $6.95 \pm 0.4$ & $6.29 \pm 1.9^{*}$ & $7.95 \pm 1.2$ & $7.92 \pm 1.0$ & $7.54 \pm 0.7$ & $10.4 \pm 3.3^{*}$ & $7.65 \pm 0.4$ \\
\hline Salinity (ppt) & $13.2 \pm 2.1$ & $29.0 \pm 5.2$ & $35.8 \pm 8.1^{*}$ & $13.1 \pm 3.3$ & $32.5 \pm 12 *$ & $21.6 \pm 2.4$ & $23.4 \pm 5.0$ & $21.4 \pm 6.1$ & $29.3 \pm 10$ & $8.39 \pm 1.6^{*}$ \\
\hline $\mathrm{EC}(\mathrm{s} / \mathrm{m})$ & $2.02 \pm 0.4^{*}$ & $4.91 \pm 0.7$ & $5.41 \pm 1.2 *$ & $3.18 \pm 1.0$ & $6.01 \pm 1.3^{*}$ & $3.44 \pm 0.3$ & $3.64 \pm 0.6$ & $3.32 \pm 0.8$ & $4.01 \pm 1.7$ & $1.24 \pm 0.1^{*}$ \\
\hline WT (C) & $19.1 \pm 0.6$ & $30.2 \pm 1.3$ & $31.1 \pm 0.8$ & $12.8 \pm 0.5^{*}$ & $23.7 \pm 4.0$ & $22.3 \pm 3.1$ & $22.3 \pm 4.9$ & $24.0 \pm 5.1$ & $25.3 \pm 5.0$ & $23.9 \pm 4.3$ \\
\hline $\mathrm{pH}$ & $7.97 \pm 0.1^{*}$ & $8.21 \pm 0.1$ & $8.20 \pm 0.1$ & $8.94 \pm 0.1$ & $8.25 \pm 0.1$ & $8.29 \pm 0.2$ & $7.94 \pm 0.0$ & $7.98 \pm 0.0$ & $8.16 \pm 0.1$ & $8.93 \pm 0.1^{*}$ \\
\hline Turbidity (NTU) & $44.0 \pm 16$ & $22.2 \pm 5.5^{*}$ & $44.5 \pm 14$ & $61.8 \pm 28^{*}$ & $10.1 \pm 3.1 *$ & $15.8 \pm 4.9$ & $82.8 \pm 36^{*}$ & $51.8 \pm 12$ & $23.1 \pm 7.7$ & $74.3 \pm 22$ \\
\hline PO 4 & $0.13 \pm 0.0$ & $0.08 \pm 0.0$ & $0.08 \pm 0.0$ & $0.22 \pm 0.1 *$ & $0.04 \pm 0.0$ & $0.05 \pm 0.0$ & $0.05 \pm 0.0$ & $0.08 \pm 0.0$ & $0.35 \pm 0.1 *$ & $0.19 \pm 0.1$ \\
\hline $\mathrm{P}$ & $0.04 \pm 0.0$ & $0.02 \pm 0.0$ & $0.02 \pm 0.0$ & $0.07 \pm 0.0^{*}$ & $0.01 \pm 0.0$ & $0.02 \pm 0.0$ & $0.01 \pm 0.0$ & $0.03 \pm 0.0$ & $0.11 \pm 0.1 *$ & $0.06 \pm 0.0$ \\
\hline $\mathrm{P} 2 \mathrm{O} 5$ & $0.09 \pm 0.0$ & $0.06 \pm 0.0$ & $0.06 \pm 0.0$ & $0.16 \pm 0.1^{*}$ & $0.03 \pm 0.0$ & $0.04 \pm 0.0$ & $0.04 \pm 0.0$ & $0.06 \pm 0.0$ & $0.26 \pm 0.1 *$ & $0.13 \pm 0.0$ \\
\hline NO3 & $1.76 \pm 0.4$ & $1.28 \pm 0.2$ & $3.02 \pm 1.4^{*}$ & $2.45 \pm 0.6$ & $3.78 \pm 2.0^{*}$ & $1.42 \pm 0.2$ & $1.25 \pm 0.2$ & $1.57 \pm 0.1$ & $2.85 \pm 1.0$ & $1.90 \pm 0.3$ \\
\hline N-NO3 & $0.46 \pm 0.2$ & $0.15 \pm 0.0 *$ & $0.66 \pm 0.3$ & $0.55 \pm 0.1$ & $0.68 \pm 0.8 *$ & $0.17 \pm 0.1$ & $0.15 \pm 0.1$ & $0.20 \pm 0.0$ & $0.40 \pm 0.4$ & $0.22 \pm 0.1$ \\
\hline $\mathrm{Si}$ & $2.45 \pm 1.2$ & $1.57 \pm 0.4^{*}$ & $2.27 \pm 0.8$ & $2.38 \pm 1.2$ & $1.07 \pm 0.3$ & $0.73 \pm 0.2$ & $1.67 \pm 0.6$ & $1.19 \pm 0.6$ & $5.10 \pm 1.0^{*}$ & $3.25 \pm 1.5$ \\
\hline $\mathrm{SiO} 2$ & $5.16 \pm 2.5$ & $3.41 \pm 0.8^{*}$ & $4.84 \pm 1.7$ & $5.08 \pm 2.5$ & $2.29 \pm 0.7$ & $1.59 \pm 0.5$ & $3.58 \pm 1.3$ & $2.56 \pm 1.4$ & $10.8 \pm 2.1 *$ & $6.86 \pm 3.3$ \\
\hline
\end{tabular}

Note: $\left(^{*}\right)$ Significant differences in a row $(\mathrm{P}<0.05)$; (DO) dissolved oxygen; $(\mathrm{WT})$ water temperature 


\section{Turbidity and electrical conductivity (EC)}

Spatial and temporal turbidity with a minimal amount of 22.2 and 10.1 (NTU) in spring and site S1 tended to increase during summer and autumn up to 61.8 and 82.8 (NTU) in S3. Electrical conductivity (EC) was low in cold season and higher at warmer season (Table 2).

Similarity and join ability among the Spatio-temporal scenarios analyzed with site-season matrix for physicochemical parameters was computed with the Jaccard index to distinguish overall different scenarios. Based on cluster analysis, 4 branches with at least $50 \%$ similarity were recognizable. Scenarios of S5AT, S5W, S6W, S6AT were distinguished from others with more than $90 \%$ disimilarity, S1SU and S5SU with about $80 \%$ similarity (Figure 2).

Inter-annually, variation of total phytoplankton density (cell. $1^{-1}$ ) ranged from $0.15 \times 10^{6}$ in February to a peak of $7.84 \times 10^{6}$ in June with mean density of $2.45 \times 10^{6}$ (Figure 3 ). The total phytoplankton density in northern sector was constant with only a peak in June. In contrast, phytoplankton density in southern sector was varying throughout the year, as months went by, and in April it tended to increase with a peak $\left(7.2 \times 10^{6}\right)$ occurred in July. Phytoplankton density in southern sector during whole summer (June to August) was more than overall mean density.

The phytoplankton assemblage of the lagoon comprised 47 species from 5 different classes including Bacillariophyta, Pyrrophyta, Chlorophyta, Cyanophyta, and Euglenophyta (Table 3). Tetraselmis gracilis is a green alga with major cell density of about 3.3 million cell per liter. Three green algae species (Crucigenia quadrata, Chlorella salina, Tetraselmis gracilis) dominated over a $50 \%$ of total cell density. While, the density Summation of Euglena oxyuris (Euglenoids), and tow Diatoms Skeletonema costatum, Rhizosolenia calcaravis contributed less than $1 \%$ of overall phytoplankton density. Thalassiosira parva very rarely occurred (2.8\%), and four species (Microcystis sp, Euglena sp, Chlorella sp, Navicula $s p$ ) occurred at least $75 \%$ in whole samples. Abundance of each species is given in Table 3 .

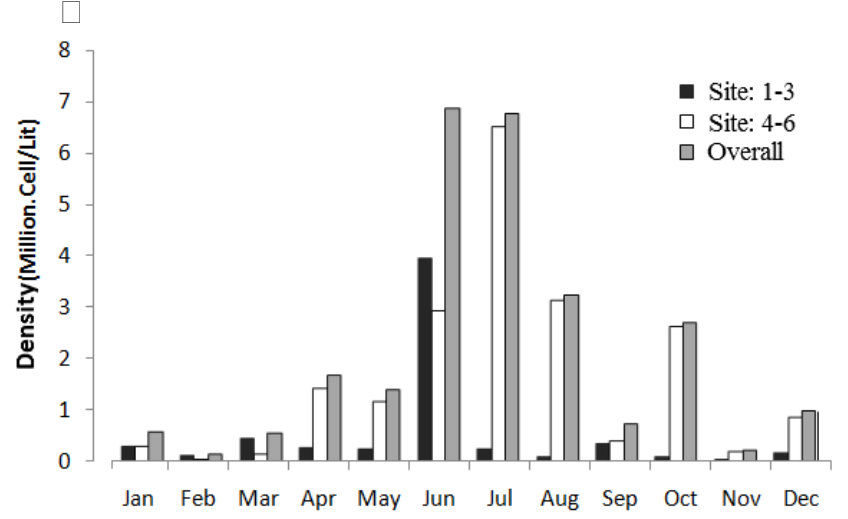

Figure 3. Total phytoplankton density changes in Gomishan Lagoon, Iran during the study period. Northern sites (S1-S3) and southern sites (S4-S6)

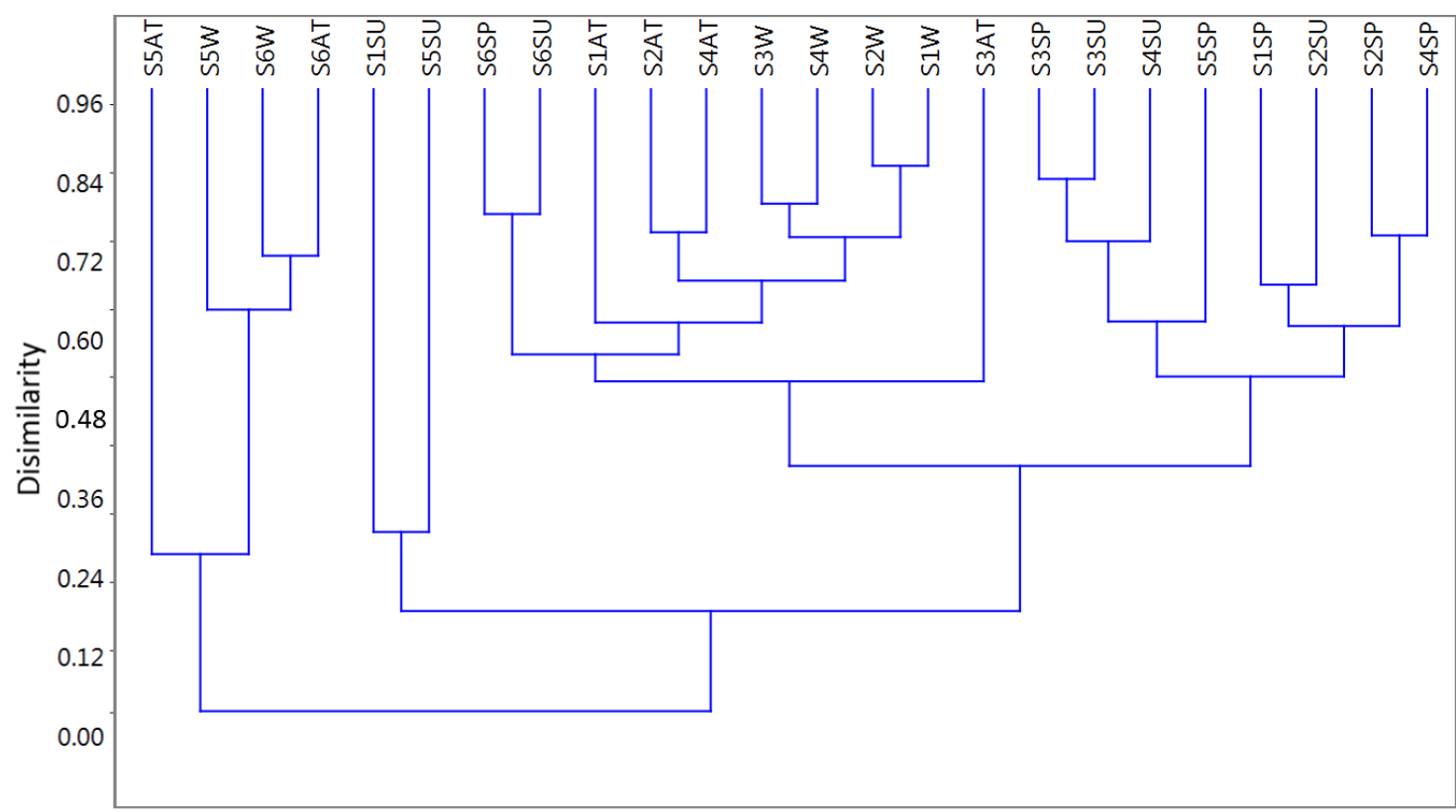

Figure 2. Spatio-temporal (dis)similarity of physic-chemical parameters in Gomishan Lagoon, Iran. Jaccard index was employed to clustering spatio-temporal scenarios 
Table 3: Composition of phytoplankton assemblage in Gomishan Lagoon. Mean Density (cell. $\left.1^{-1}\right)$ and Occurrence of each species are given (2014-2015)

\begin{tabular}{|c|c|c|}
\hline \multirow{2}{*}{$\begin{array}{l}\text { Species } \\
\text { Anabaena } \text { sp. }\end{array}$} & \multicolumn{2}{|c|}{ Mean density \pm SE Occurrence $(\%)$} \\
\hline & $291337 \pm 100872$ & 66.6 \\
\hline Anabaena spirodes & $282000 \pm 122000$ & 8.3 \\
\hline Chaetoceros sp. & $3350 \pm 1350$ & 8.3 \\
\hline Chlamydomonas ovalis & $39222 \pm 10021$ & 50 \\
\hline Chlorella marina & $170000 \pm 60000$ & 8.3 \\
\hline Chlorella salina & $709000 \pm 419000$ & 8.3 \\
\hline Chlorella sp. & $85181 \pm 19830$ & 91.6 \\
\hline Chroococcus limenticus & $221333 \pm 149336$ & 12.5 \\
\hline Chroococcus turgidus & $17666 \pm 3527$ & 12.5 \\
\hline Coconeis scutellum & $20000 \pm 5050$ & 4.1 \\
\hline Coconeis sp. & $22410 \pm 13521$ & 4.1 \\
\hline Crucigenia quadrata & $567000 \pm 196071$ & 20.8 \\
\hline Cyclotella menenghiniana & $5900 \pm 100$ & 8.3 \\
\hline Euglena oxyuris & $1200 \pm 700$ & 4.1 \\
\hline Euglena sp. & $24333 \pm 5811$ & 75 \\
\hline Gonyaulax tamarensis & $6646 \pm 3416$ & 12.5 \\
\hline Gymnodinium sp. & $18100 \pm 4102$ & 25 \\
\hline Kirchneriella obesa & $8000 \pm 4800$ & 4.1 \\
\hline Mersmopedia punctata & $3656 \pm 2100$ & 4.1 \\
\hline Mersmopedia sp. & $40000 \pm 15000$ & 4.1 \\
\hline Microcystis sp. & $15916 \pm 1961$ & 75 \\
\hline Nannochloris atomus & $5400 \pm 3200$ & 4.1 \\
\hline Navicula bombus & $5000 \pm 3800$ & 4.1 \\
\hline Gonyaulax tamarensis & $6646 \pm 1641$ & 12.5 \\
\hline Navicula $\mathrm{sp}$ & $96673 \pm 2645$ & 95.8 \\
\hline Nitzschia closterium & $146740 \pm 96740$ & 16.6 \\
\hline Nitzschia longissima & $345000 \pm 145000$ & 4.1 \\
\hline Nitzschia sp. & $62812 \pm 12215$ & 50 \\
\hline Oscillatoria sp. & $17100 \pm 7230$ & 4.1 \\
\hline Peridinium sp. & $33940 \pm 9045$ & 12.5 \\
\hline Pleurosigma delicatulum & $5500 \pm 1850$ & 8.3 \\
\hline Pleurosigma elongatum & $26000 \pm 6234$ & 12.5 \\
\hline Pleurosigma strigosum & $3600 \pm 737$ & 20.8 \\
\hline Prorocentrum micans & $21528 \pm 14046$ & 20.8 \\
\hline Prorocentrum minimum & $17990 \pm 5195$ & 41.6 \\
\hline Protoeridinium conicoides & $66500 \pm 12500$ & 8.3 \\
\hline Protoperidinium sp. & $35866 \pm 17099$ & 12.5 \\
\hline Rhizosolenia calcaravis & $1800 \pm 1069$ & 4.1 \\
\hline Scenedesmus acuminatus & $14675 \pm 4190$ & 16.6 \\
\hline Scenedesmus quadricauda & $76500 \pm 37500$ & 8.3 \\
\hline Skeletonema costatum & $1000 \pm 600$ & 4.1 \\
\hline Spirulina sp. & $44333 \pm 21211$ & 25 \\
\hline Spirulina subsalsa & $5250 \pm 3050$ & 8.3 \\
\hline Synechococcus sp. & $8500 \pm 50$ & 8.3 \\
\hline Tetraselmis gracilis & $3292667 \pm 1330951$ & 12.5 \\
\hline Thalassiosira parva & $48700 \pm 20792$ & 2.8 \\
\hline Triblionella hungarica & $35000 \pm 11000$ & 4.1 \\
\hline
\end{tabular}

As a result of seasonal change, Diatoms had relatively high assemblage proportion (total mean of seasonal proportion $=30 \%$ ) with only one significant decrease in summer to $3 \%$ of total phytoplankton (Figure 4). Decreasing pattern of Dinoflagellates was from $7 \%$ in winter to $0.15 \%$ in autumn. Top level of Green algae $(78 \%)$ in summer tended to decrease during autumn, winter, and to $24 \%$ in spring. Cyanobacteria's highest proportion occurred in spring (78\%) and steadily decreased during summer, autumn to the lowest level of $8 \%$ in winter.
Euglenoids pattern from summer $(0 \%)$ tended to increase during autumn $(2 \%)$, winter $(3 \%)$, to a temporal peak in spring. Spatial analysis showed that site S1 was dominated by green algae with $79 \%$ of total density, site S2, and S3 had relatively balanced composition with increasing proportion of Dinoflagellates, green algae, Diatoms, Cyanobacteria, Euglenoids, respectively. In site S4 tow groups including green algae and Cyanobacteria were more than $83 \%$ of total phytoplankton density and site S5 was dominated by green algae $(82 \%)$. Site S6 assemblage contained Cyanobacteria $(60 \%)$, while three groups (Diatoms, Dinoflagellates, Euglenoids) were less than 7\% (Figure 4). Additionally, the dominant species of each functional groups (Diatoms, Dinoflagellates, Cyanobacteria, Green algae, and Euglenoids) were Nitzschia longissima, Protoeridinium conicoides, Anabaena sp., Tetraselmis gracilis, and Euglena sp., respectively.

The biplot of Principle Component Analysis (PCA) demonstrated ordination pattern of 5 phytoplankton groups in 6 study sites (Figure 5). We found relative separation of site S5 in positive ordinate of both components with fewer points overlapping in the middle which was well correlated with 3 groups of phytoplankton (Euglenoids, Green algae, and Diatoms). Sites S6 and S2 can be found only in negative side of component 1 that were negatively correlated with Dinoflagellates. However, sites S1, S3, and S4 have most overlap with together in both ordinations (Figure 5).

Environmental parameters-species relations based on first tow components correlation matrix using data series of four season assemblage revealed that Diatoms such as Navicula sp. Nitzschia sp. and Chaetoceros sp. as well as Chlorella sp. that was a green algae were correlated best toward positive side of axis 1 and negative side of axis 2 which shows positive correlation with factors of EC, total Nitrogen, and Salinity that address the distribution condition (Figure 6). Meanwhile, Euglenoids (Euglena sp.) were correlated positively along both axes which are total phosphorus, and total silica. Cyanobacteria's species such as (Anabaena sp. and Chroococcus limenticus) show more different range of correlation with Turbidity in negative side of axis 1 to DO in positive side. Green algae such as (Clamydomonas ovalis, Crucigenia quadrata, and Chlorella sp.) were positively correlated with parameters of $\mathrm{pH}$, water temperature and negatively correlated with Turbidity. Dinoflagellates were correlated with all environmental parameters equally. However, species such as Prorocentrum micans and Prorocentrum minimum were positively correlated with turbidity (and negatively in some sites and season) and with water temperature (Figure 6).

\section{Discussion}

According to Chan and Hamilton (2001), spatial changes of phytoplankton communities observed in Gomishan Lagoon can be explained by environmental parameter tolerance. In addition, seasonal dominance of phytoplankton groups depends on resources and physical factors (Fogg 1991). Therefore, applied spatiotemporal scenarios of this research can address seasonal succession 
and spatial heterogeneity by cluster similarity analysis. (Dis)Similarity cluster analysis indicates that southern Gomishan Lagoon during cold season (winter and autumn) and northern site during warm season (summer) were the most different scenarios related to physicochemical parameters.

Salinity has the biggest effect on phytoplankton dominance (Varona-Cordero et al. 2010) salinity of
Gomishan Lagoon was tolerant with river inflow in the south, however, in the northern part of the lagoon it changed by season and temperature due to shallowness. Minimum and maximum of salinity were measured in the north (summer) and south (autumn), relatively. Therefore, the most seasonal dissimilarity of physico-chemical factors occurred in the related scenarios.
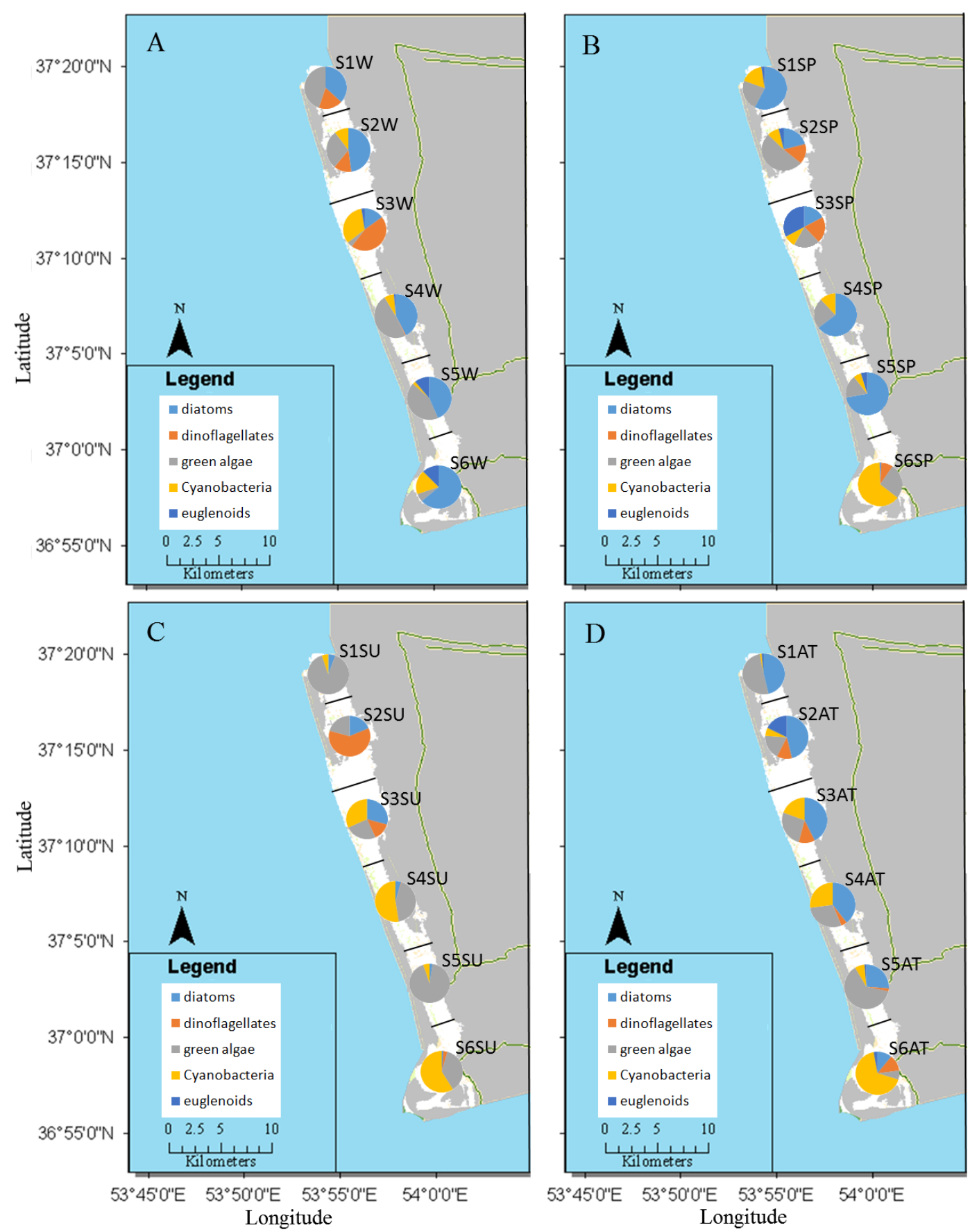

Figure 4. Spatio-temporal distribution of phytoplankton in Gomishan Lagoon (2014-2015). Study sites were (S1 to S6) during seasons (A) winter, (B) Spring, (C) Summer, (D) Autumn 


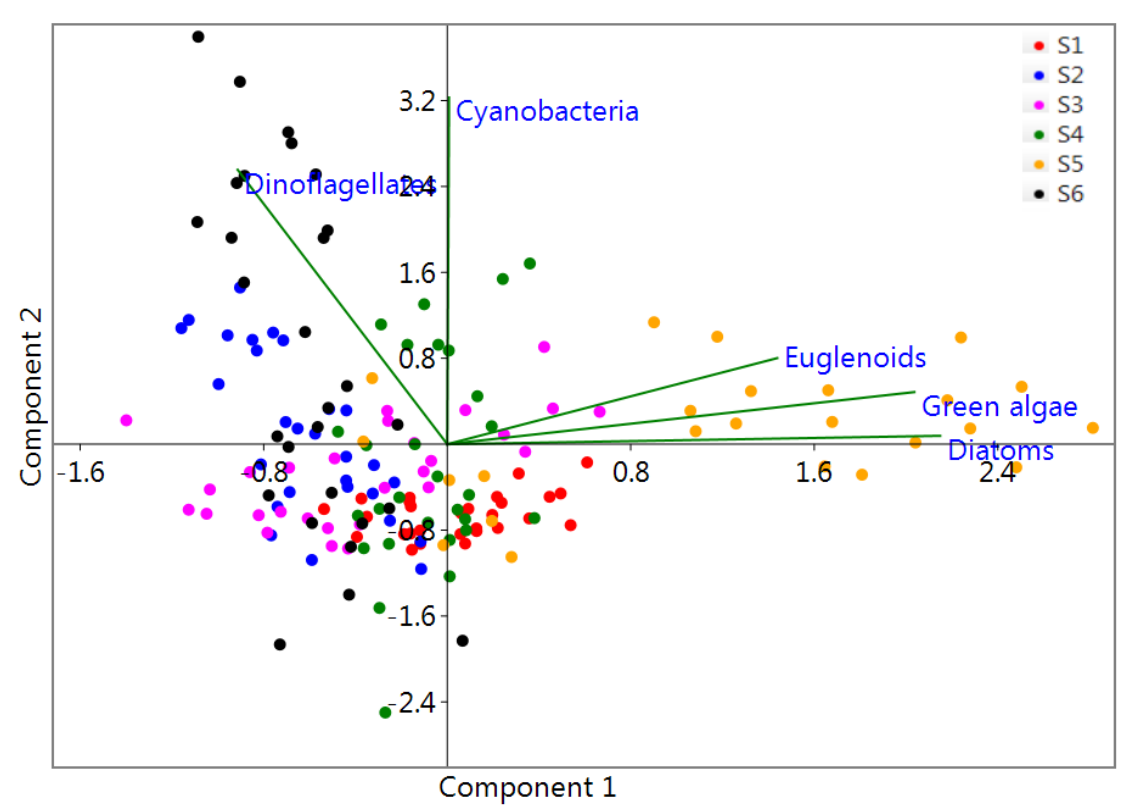

Figure 5. Spatial separation based on the PCA matrix. Log-transformed abundance of 5 phytoplankton groups is used to establish principle components $\square$

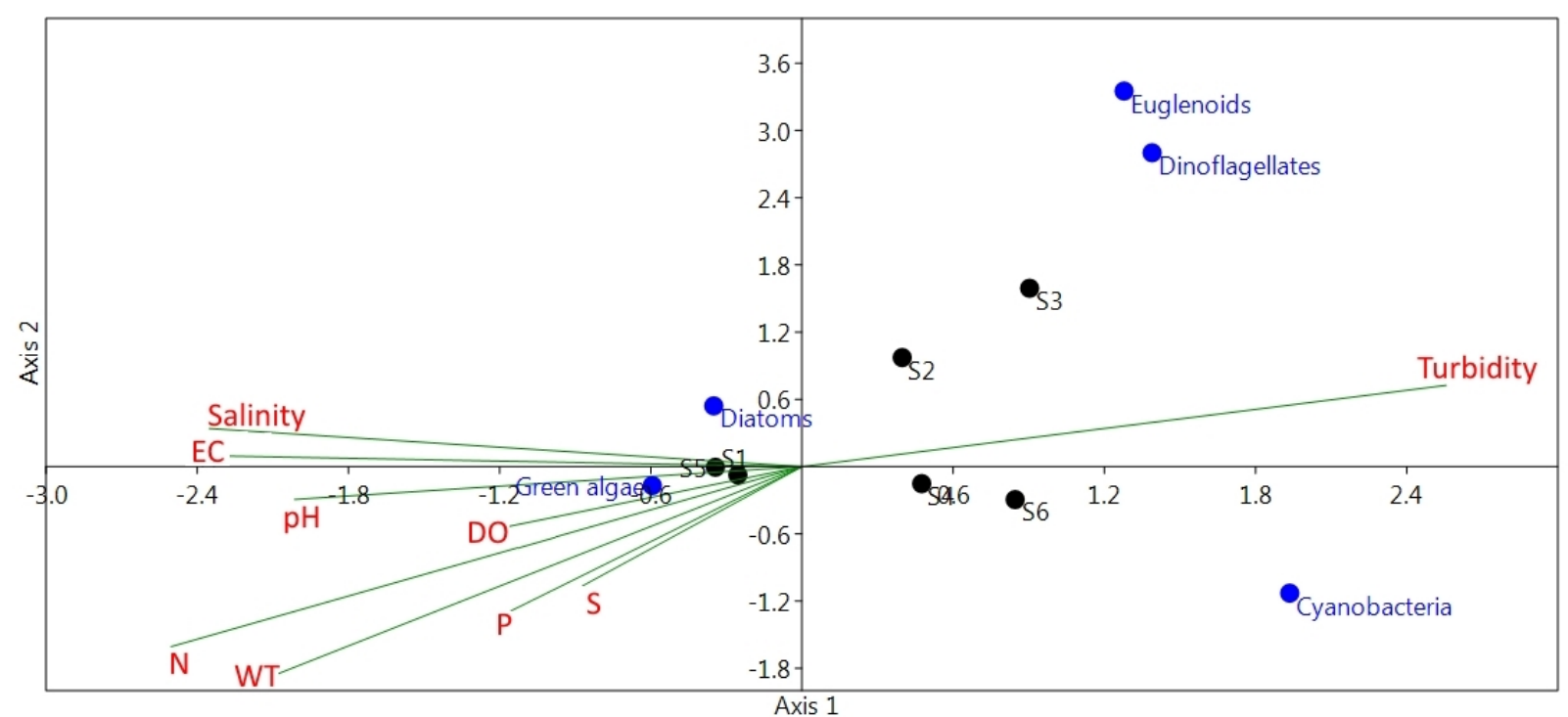

Figure 6. Environmental parameters-species correlation using canonical correspondence analysis (CCA) between 9 sets of physicochemical variables and collected phytoplankton species. P, S, WT, and N stand for total phosphorus, total silica, water temperature, and total nitrogen, relatively

Meso-saprobic phytoplankton groups such as Chlorophyta occurred during whole year which shows that these groups are more adaptable group (Esmaili-Sari 2001). However, common temperate blue green algae that are implemented in harmful algae bloom (HAB) such as Anabaena sp. that were the dominant species within the group (Cyanobacteria) occurred only in warm season. In total, brackish centric Diatoms such as Pleurosigma delicatulum, Pleurosigma strigosum, Thalassiosira parva, Chaetoceros sp., Nitzschia longissima, Nitzschia closterium, Nitzschia sp., Navicula sp., Coconeis sp., Rhizosolenia calcaravis, Triblionella hungarica were the most diverse group of phytoplankton in Gomishan Lagoon (Khelfeh 2009). Seasonal taxa analysis revealed that taxa diversification in Gomishan Lagoon during spring was the highest, while during winter the identified number of species was minimum.

Generally, small-chained diatoms such as genus Skeletonema have been seen in the beginning of the bloom (Suthers and Rissik 2009). The occurrence of Skeletonema 
costatum in site S6 during summer and high density of Cyanobacteria and Dinoflagellates in this site made this scenario potentially had the most evidence for occurring of HAB. Pinnate Diatoms including Genus Navicula were present all over the year and reached a peak in summer.

According to Kiabi et al. (1999) and our study, some species in Gomishan Lagoon have yet to be fully defined such as (Anabaena sp., Synechococcus sp., Microcystis sp., Scillatoria sp., Mersmopedia sp., Spirulina sp., Chaetoceros sp., Coconeis sp., Nitzschia sp., Navicula sp., Gymnodinium sp., Peridinium sp., Protoperidinium sp., Euglena sp., Chlorella sp.). Basically more identification studies are needed.

In conclusion, Gomishan Lagoon had high variation of heat through northern to southern parts. Among all the environmental factors, salinity had the most influence on phytoplankton communities, thus salinity is the key factor in controlling plankton communities. Meso-saprobic phytoplankton communities such as Chlorophyta are the most adaptable group in Gomishan Lagoon. Phytoplankton community had high biodiversity during spring season. Southern part had the most potential vulnerability to harmful algae bloom in Gomishan Lagoon.

\section{ACKNOWLEDGEMENTS}

We are grateful to anonymous reviewers and sampling assistants for their helpful collaborate. We also thank Gorgan University of Agricultural Science and Natural Resources, Iran for laboratory facilities.

\section{REFERENCES}

APHA. 2012. Standard methods for the examination of water and waste water, 23nd ed. American Public Health Association, Washington, DC.

Barbone E, Basset A. 2010. Hydrological constraints to macrobenthic fauna biodiversity in transitional waters ecosystems. Rendiconti Lincei 21 (4): 301-314.

Bartram J, Ballance R. 1996. Water quality monitoring: a practical guide to the design and implementation of freshwater quality studies and monitoring programmes. CRC Press, London.

Chan TU, Hamilton DP. 2001. Effect of freshwater flow on the succession and biomass of phytoplankton in a seasonal estuary. Mar Freshw Res 52 (6): 869-884.
Cloern JE. 1996. Phytoplankton bloom dynamics in coastal ecosystems: a review with some general lessons from sustained investigation of San Francisco Bay, California. Rev Geophys 34 (2): 127-168.

Esmaili-Sari A. 2001. Plankton ATLAS of Iran. Iranian Fisheries Research Organization (IFRO), Tehran.

European Communities. 2000. Directive 2000/60/EC of the European Parliament and of the Council of 23 October 2000 establishing a framework for Community action in the field of water policy. Official J Eur Commun 43 (L327): 75.

Fogg G. 1991. The phytoplanktonic ways of life. New Phytol 118 (2): 191-232.

Khelfeh NSM. 2009. Planktonic Frequency and Biodiversity survey of Shadegan wetland and determination of its trophic status. Journal of Marine Biology, Ahvaz, 1(3) :1-13

Kiabi BH, Ghaemi RA, Abdoli A. 1999. Wetland and Riverian Ecosystems of Golestan Province. Department of the Environment, Gorgan.[ Persian].

Kirk JT. 1994. Light and photosynthesis in aquatic ecosystems. Cambridge University press, London.

Marshall HG. 1986. Identification manual for phytoplankton of the United States Atlantic Coast. Environmental Monitoring and Support Laboratory, Office of Research and Development, US Environmental Protection Agency, Washington, D.C.

Moncheva S, Parr B. 2010. Manual for Phytoplankton Sampling and Analysis in the Black Sea. Phytoplankton Manual, UP-GRADE Black Sea Scene Project, FP7(226592), Istanbul, Turkey.

Nielsen ES. 1975. Marine Photosynthesis. Vol. 13. Elsevier, New York.

Odum EP, Odum HT. 1959. Fundamentals of Ecology. W.B. Saunders Company, Philadelphia.

Paerl HW. 1988. Nuisance phytoplankton blooms in coastal, estuarine, and inland waters. Limnol Oceanogr 33 (4part2): 823-843.

Philips E, Badylak S, Grosskopf T. 2002. Factors affecting the abundance of phytoplankton in a restricted subtropical lagoon, the Indian River Lagoon, Florida, USA. Estuar Coast Shelf Sci 55 (3): 385-402.

Hails A. 1997. Wetlands, biodiversity and the Ramsar convention: the role of the convention on wetlands in the conservation and wise use of biodiversity. Ramsar Convention Bureau Gland, Switzerland.

Smayda, T. 1980 Species Succession. In, I. Morris [ed.] The Physiological Ecology of Phytoplankton.. Univ. Calif. Press, Berkeley, California, USA.

Spatharis S, Tsirtsis G, Danielidis DB et al. 2007. Effects of pulsed nutrient inputs on phytoplankton assemblage structure and blooms in an enclosed coastal area. Estuarine, Coastal and Shelf Science 73 (3): 807-815.

Suthers IM., Rissik D. 2009. Plankton: A guide to their ecology and monitoring for water quality. Csiro Publishing, Clayton, Australia.

Varona-Cordero F, Gutiérrez-Mendieta FJ, del Castillo MEM. 2010. Phytoplankton assemblages in two compartmentalized coastal tropical lagoons (Carretas-Pereyra and Chantuto-Panzacola, Mexico). J Plankton Res 32 (9): 1283-1299.

Viličić D. 1989. Phytoplankton population density and volume as indicators of eutrophication in the eastern part of the Adriatic Sea. Hydrobiologia 174 (2): 117-132. 